\title{
Reflections on the occasion of my birthday, by Mr Davy
}

$\mathbf{I}_{\mathrm{T}}^{\mathrm{T}}$

T has been a matter of some gratification to $\mathrm{me}$, in my present rather distant circumstances, to note that the Anniversary of my birth has not gone unnoticed by your esteemed Journal. I refer, Sir, to the remarkably accurate and well executed likeness of the lamp which is associated with my name, that occupies the entirety of your frontispiece. By the yardstick of eternity two hundred years is a mere nothing. It would be churlish to complain of a lack of recognition, were it not that various dabblers and meddlers have received more than their proportionate share of such credit as your transitory World offers. It is true that the Royal Institution has seen fit to mark this Anniversary with an exhibition. But why is access restricted to Tuesdays and Thursdays between the paltry hours of noon and four? And why do they charge a derisory fleabite of only twenty pence? In 1811, in Dublin, tickets cost two whole guineas to hear me lecture on 'Peculiar Observations in Electrochemistry'. And even so all five hundred and fifty tickets were sold within a week. Subsequently I was told the self-same tickets changed hands on the street at up to twenty guineas apiece! In those days Chemistry was much more popular as a subject for lectures, than Astronomy, Mechanics, or Natural History. A critic wrote, 'These subjects are not susceptible of any brilliant exhibitions; there is no noise, no fire-and the amphitheatre never fills, but for $\mathrm{Mr}$ Davy. A small bit of Potassium thrown in a glass of water, or upon a piece of ice, never fails to excite a gentle murmur of applause! And the audience consisted of young Gentlemen together with an equivalent number of young Ladies of High Quality.'

1 know that Dalton and Faraday have done very well since-they have Divisions named after them in the Chemical Society. But as for Dalton all that talk about atoms; it was mere speculation, no experimental evidence. As I said at the time, 'it's more ingenious than important'. And as for $\mathrm{Mr}$ M. Faraday, I very much resent those who say that he was my greatest discovery. Let me remind you that, whatever became of him afterwards, he was only my Assistant. He may have discovered the Laws, but I discovered the Elements: Sodium, Potassium, Calcium, Magnesium, Barium, Strontium and Chlorine. Electricity from my Giant Pile was able to exert a power on substances such as had not been exerted before. Even mighty Soda and Potash yielded themselves to sustained attack. Not all Savants could accept my simple view of the little molten globules emerging through the crust of the potash and bursting into purple flame. This was not to be the last time that Gay-Lussac and his henchman Thenard obstructed the course of Natural Philosophy. Carried away by their isolation of Boron-a remarkable achievement for them-I may have perchance referred to Gay-Lussac as being the Head of Living Chemists in France. But their notion that $m y$ Potassium was a mere Hydride of Potash could not be sustained and can only be regarded as being vexatious. No wonder I resent Gay-Lussac's Bicentennial- -200 francs a head, no half price for children and open all the week including Sundays! I grant you that M. Lussac was a competent experimentalist; somehow his numbers always fitted. But Laws are merely reflections of Man's puny attempts to describe the omnipotence of the Supreme Being:

"All things most glorious on the Earth Tho' transient and short lived they seem, Have yet a source of heavenly birth Immortal, - not a fleeting dream"

And I speak of Experiments, not Laws. As I once said, 'It is more laborious to accumulate facts than to reason concerning them; but one good experiment is of more value than the ingenuity of a brain like Newton's.'.

My first experiments were conducted in Mr Tonkin's house in Penzance and relied on such apparatus as wine-glasses, tea-cups, tobacco-pipes and crucibles, securing preference upon the kitchen stove to the more ordinary domestic comestibles. I shall always be beholden to the generosity of $\mathrm{Dr}$ Thomas Beddoes and the Pneumatic Institute of Bristol but it was at the Royal Institution, following the work of Nicholson and Carlisle, that I demonstrated that Hydrogen and Oxygen alone were the true products of galvanic action on pure water. I discovered to my manifest astonishment that the two gases could be separated if two gold plates, dipped into separate vessels of water were linked by the fingers of my own hands. This was not the first time that my body had been used as a tool in the Laboratory. And, a fig, Sir, for your Health and Safety at Work Act! In 1806 I demonstrated the relation of electricity to chemistry using three vessels connected by moist fibres. In front of the very eyes of an audience, I immersed metal plates in two outer vessels containing Barium Nitrate and Sodium Sulphate and these outer vessels were linked each to the other through a third vessel containing pure water. The action of the Giant
Pile on this apparatus brought forth a magnificent deposition of solid white Barium Sulphate in the middle vessel. Such a spectacle could only be interpreted as a manifestation of Nature's innermost Secrets. For the first time I realised that some substances were attracted and some repelled by the quality of the electrification of the plates. I declared 'These attractive and repulsive forces are sufficiently energetic to destroy or suspend the usual operation of Chemical Affinity'. One cannot speculate with profit on the nature of electricity, but 1 had no doubt it was connected with Chemical Affinity and the very essence of Matter.

The Lamp you have, Sir, in your frontispiece, should not be the only reminder to your Readers of the festive Season. Why, Sir, on Boxing Dayaptly named-in 1799 / discovered the medical properties of Nitrous Oxide. I enclosed myself in an airtight breathing box, having a cubic capacity of about nine and a half cubic feet. I was in the box for one and a quarter hours, and breathed over twenty quarts of pure nitrous oxide. A thrilling extending from the chest to the extremities was almost immediately produced. I felt a sense of tangible extension, highly pleasurable in every limb; my visible impressions were dazzling and apparently magnified. By degrees as the pleasurable sensations increased, I lost all connection with external things; trains of vivid visible images rapidly passed through my mind and were connected with words in such a manner, as to produce perceptions perfectly novel. I existed in a World of newly connected and newly modified ideas. I theorised; I imagined that I made discoveries. And that is why, Sir, I crave the courtesy of your columns to enquire why I should be remembered only by my Lamp (as if I was Miss Nightingale) rather than as the Father of British Anaesthesia. I need hardly remind you that the Poet Southey wrote 'Davy has invented a new pleasure for which language has no name. I am going for more this evening, it makes me strong and happy! So gloriously happy! Oh, excellent air-bag!' And in 1801 Wordsworth and Coleridge beseeched me to teach them Chemistry in a special Laboratory to be constructed at Keswick. Had I acceded to their request and gone to the Lake District, rather than the Royal Institution, the benefits to English Literature and to Chemistry remain to this day, Sir, incalculable. 